This article has been accepted for publication in Legal Studies

[https://www.cambridge.org/core/journals/legal-studies]. This version is free to view and download for private research and study only. Not for re-distribution, re-sale or use in derivative works. (C) Alysia Blackham.

\title{
ENFORCING RIGHTS IN EMPLOYMENT TRIBUNALS: INSIGHTS FROM AGE DISCRIMINATION CLAIMS IN A NEW 'DATASET'
}

\begin{abstract}
ALYSIA BLACKHAM*
The online publication of Employment Tribunal (ET) decisions in England, Wales and Scotland marks a watershed moment, opening up new innovative avenues for legal research, and promoting transparency in labour law decision-making. Drawing on this 'dataset', and using age discrimination decisions as a lens to facilitate analysis, this paper reflects on the advantages and limitations of using online ET decisions as a data source to support labour law research. By considering matters of time in age discrimination decisions - both in relation to time limits for bringing a claim, and ET delays - this paper uses innovative empirical findings to map the limits of the individual enforcement model adopted by discrimination laws, and illustrates some of the barriers to successfully bringing a claim for discrimination.
\end{abstract}

Keywords: labour law; equality law; Employment Tribunals; age discrimination; individual enforcement; Great Britain

1

INTRODUCTION

From February 2017, Employment Tribunal (ET) decisions in England, Wales and Scotland have been published online, becoming freely accessible to practitioners, the general public, employers and academic researchers. ${ }^{1}$ The online publication of ET decisions marks a watershed moment for legal researchers: as discussed in Part II, accessing ET decisions used to be difficult, time consuming and potentially expensive. It is now none of these things, opening up new innovative avenues for legal research.

\footnotetext{
* Associate Professor and Discovery Early Career Research Fellow, Melbourne Law School, The University of Melbourne. This research was funded by the Australian Government through the Australian Research Council's Discovery Projects funding scheme (Project DE170100228). The views expressed herein are those of the author and are not necessarily those of the Australian Government or Australian Research Council.

${ }^{1}$ GOV.UK, Employment Tribunal Decisions <https://www.gov.uk/employment-tribunal-decisions>.
} 
This empirical paper uses this new 'dataset' to conduct a case study of the individual enforcement of age discrimination law in the UK. ${ }^{2}$ Using Python, age discrimination cases published up to 17 April 2019 were extracted from the ET website, and inserted into a spreadsheet for analysis, creating a new dataset of 1208 age discrimination cases (see Part III). Qualitative and quantitative content analysis was conducted of all 1208 cases, to provide a clear illustration of how age discrimination claims proceed and are resolved in ETs.

Drawing on this dataset, this paper reveals in Part IV that the vast majority of age discrimination claims are unsuccessful in ETs. While most claims are withdrawn (whether settled or abandoned), those that do progress to hearing are unlikely to be successful. Further, particular demographic groups appear more willing or able to enforce their rights in ETs. To further illustrate the ways in which the ET decision 'dataset' might be used in practice, in Part V I consider matters of time in age discrimination decisions, both in relation to time limits to bring a claim, and ET delays.

These findings challenge the individual enforcement model adopted by discrimination laws and illustrate the barriers to successfully bringing a claim for discrimination. Using age discrimination decisions as a lens to facilitate analysis, in Part VI the paper reflects on the advantages and limitations of using online ET decisions as a data source to support labour law research, and considers the ways in which online ET decisions might be used to advance future legal research projects.

\footnotetext{
${ }^{2}$ This paper typically refers to the UK as a whole, though the differences between the regimes in England and Wales, Scotland and Northern Ireland are referenced as appropriate.
} 
In the UK, the enforcement of discrimination law (like individual labour law rights more generally) primarily depends on individuals bringing claims. ${ }^{3}$ In relation to the workplace, discrimination claimants must first notify the statutory body Acas (the Advisory, Conciliation and Arbitration Service) or the Northern Ireland (NI) Labour Relations Agency of their claim (the 'early conciliation' process). ${ }^{4}$ If the claim is not successfully conciliated, it may be filed with the relevant ET (or, in NI, the Industrial Tribunal or Fair Employment Tribunal). ETs hear and adjudicate the vast majority of discrimination claims in the $\mathrm{UK},{ }^{5}$ though only a small minority of claimants will pursue their case to a public hearing and judgment. ${ }^{6}$ First-instance ET decisions, while having no precedential weight, offer important insights into the operation of individual enforcement in the UK. ${ }^{7}$

However, until February 2017, ET decisions were notoriously difficult to access. In England and Wales, unless the parties or judiciary website chose to publish the decision, or it was selected for commercial publication, it was necessary to physically travel to the registry in Bury St Edmunds to locate a decision, or to file a written request and pay a fee for a decision's retrieval (£10, plus $£ 5$ for each additional decision). ${ }^{8}$ Issues also arose with how judgments

\footnotetext{
${ }^{3}$ Linda Dickens, 'The Road Is Long: Thirty Years of Equality Legislation in Britain' (2007) 45(3) British Journal of Industrial Relations 463, 475.

${ }^{4}$ Enterprise and Regulatory Reform Act 2013, s 7; The Employment Tribunals (Early Conciliation: Exemptions and Rules of Procedure) Regulations 2014, SI 2014/254. Notification was not compulsory prior to 2014. Early conciliation was introduced in NI from 27 January 2020: The Industrial Tribunals and Fair Employment Tribunal (Early Conciliation: Exemptions and Rules of Procedure) Regulations (Northern Ireland) 2020, SI 2020/2.

${ }^{5} \mathrm{Cf}$, eg, the limited age discrimination case law in the courts: Alysia Blackham, 'Age Discrimination beyond Employment' (2019) 52(1) Kobe University Law Review 1.

${ }^{6}$ See, eg, Laura Beth Nielsen and Robert L Nelson, 'Scaling the Pyramid: A Sociolegal Model of Employment Discrimination Litigation' in Laura Beth Nielsen and Robert L Nelson (eds), Handbook of employment discrimination research: rights and realities (Springer, 2005) 3.

${ }^{7}$ See, eg, Catherine Barnard and Amy Ludlow, 'Enforcement of Employment Rights by EU-8 Migrant Workers in Employment Tribunals' (2016) 45(1) Industrial Law Journal 1.

8 BIALL How Do I? Wiki / Employment Tribunal Cases (9 February 2017) BIALL $<$ http://biallpr.pbworks.com/w/page/5259170/Employment\%20Tribunal\%20cases $>$.
} 
were stored and archived: Bury St Edmunds ceased to hold decisions more than 6 years old, and the location for storing the archive of decisions was not determined. ${ }^{9}$ It is unclear where these historical decisions are now located. Scottish ET decisions similarly needed to be obtained separately from the relevant ET office where the case was heard (Aberdeen, Dundee, Edinburgh or Glasgow). NI decisions have been accessible online since the commencement of age discrimination law. ${ }^{10}$

Existing academic research reveals just how complicated this made the analysis and scrutiny of ET decisions. Lockwood and others analysed a sample of 317 ET decisions relating to sexual harassment decided between 1995 and 2005. ${ }^{11}$ Rather than accessing files at Bury St Edmunds, however, the authors were unexpectedly able to obtain cases directly from the then Equal Opportunity Commission, which received relevant cases directly from the Tribunals service. ${ }^{12}$ However, the authors noted that the difficulties in accessing ET decisions, and a resulting lack of data, meant that debates around sexual harassment were occurring without any systemic understanding of ET litigation. ${ }^{13}$

In her PhD thesis, Irving analysed all ET decisions in England and Wales relating to claims under the Employment Equality (Age) Regulations 2006, SI 2006/1031 from the Regulations' commencement (1 October 2006) to 1 April 2010, that were held at Bury St Edmunds. This entailed identifying each decision on a computer database, then using the folio number of the

\footnotetext{
${ }^{9}$ Ibid.

${ }^{10}$ Northern Ireland Industrial Tribunals and Fair Employment Tribunals, Decisions Search (28 September 2006) $<$ https://employmenttribunalsni.co.uk/OITFET_IWS/DecisionSearch.aspx>.

${ }^{11}$ G Lockwood, P Rosenthal and A Budjnaovcanin, 'A Quantitative and Qualitative Analysis of Sexual Harassment Claims 1995-2005' (2011) 42(1) Industrial Relations Journal 86; see also Patrice Rosenthal and Alexandra Budjanovcanin, 'Sexual Harassment Judgments by British Employment Tribunals 1995-2005: Implications for Claimants and Their Advocates' (2011) 49(S2) British Journal of Industrial Relations s236. 12 Lockwood, Rosenthal and Budjnaovcanin, above n 11, 88.

13 Ibid.
} 
decision to retrieve hard copy information in a separate file. ${ }^{14}$ At that time, the computer database could only retrieve a certain number of records, meaning Irving had to search across a number of time periods to identify all relevant decisions. ${ }^{15}$ Using this time-consuming method, Irving identified 4001 age discrimination cases in England and Wales. ${ }^{16}$ However, most claims did not result in a judgment; Irving's analysis is therefore based on the $32 \%$ of claims that did result in a judgment. ${ }^{17}$

Barnard and Ludlow later examined ET files at Bury St Edmunds to consider how EU-8 nationals enforced their employment rights in England and Wales. ${ }^{18}$ Examining all ET decisions held at Bury St Edmunds from 1 January 2010 to 31 December 2012, Barnard and Ludlow coded decisions where 'there was evidence to suggest that the claimant was an EU-8 migrant worker'. ${ }^{19}$ As Barnard and Ludlow found, there was no easy way to determine nationality on the ET Judgment Register. ${ }^{20}$ Instead, the researchers relied on a number of assumptions to 'trigger' their examination of a case file, including around the claimant's name, a reference to nationality in the decision itself, and the nature of the dispute. ${ }^{21}$ This generated a dataset of 1,548 decisions; ${ }^{22}$ however, following further scrutiny, the researchers identified only 46 cases where they could say with certainty that the claimant was an EU-8 migrant worker. ${ }^{23}$ This research was enabled by grant funding and research assistance. It illustrates both

\footnotetext{
${ }^{14}$ LD Irving, Challenging Ageism in Employment: An Analysis of the Implementation of Age Discrimination Legislation in England and Wales (Coventry University, 2012) $<$ https://curve.coventry.ac.uk/open/file/ffc88163-6994-4400-bead-121298f52bd1/1/Irving\%202012.pdf>. 15 Ibid 76.

${ }^{16}$ Somewhat ironically, some of Irving's results tables are not available in the online version of the PhD thesis, but must be inspected in hard copy at Coventry University.

${ }^{17}$ Irving, above n 14, 86.

${ }^{18}$ Barnard and Ludlow, above $\mathrm{n} 7$.

${ }^{19}$ Ibid 3.

${ }^{20}$ Ibid 6.

${ }^{21}$ Ibid.

${ }^{22}$ Ibid 8.

${ }^{23} \mathrm{Ibid}$ 7, 10.
} 
the practical difficulties of collecting and analysing ET decisions, and the limited information that is present in many ET decisions. As Barnard and Ludlow explain,

The strongest evidence of EU-8 nationality in our dataset is where there was an express reference to EU-8 nationality in the ET decision ... only approximately $10 \%$ of our dataset $(n$ $=148$ ) included [this express reference]. We were surprised by this, given the prevalence of discrimination claims within our dataset and the relevance of nationality to those claims. ${ }^{24}$

Even where information is highly relevant to an ET's decision-making process (such as nationality in a discrimination claim), it is not necessarily included in the written ET decision. This is consistent with the findings of this study (see further below). These studies illustrate the practical complexity, cost and empirical limitations of studying hard copy ET decisions. All of these studies limited their scope to decisions in England and Wales, and did not attempt to visit the various tribunal offices in Scotland.

Without ready access to ET decisions, it is difficult to assess the practical effectiveness (or otherwise) of the individual enforcement model. This is compounded by the limited data collected and published by the tribunals themselves. As revealed in Barnard and Ludlow's study, for example, there is no official data relating to the number of EU-8 migrant workers who bring ET claims. ${ }^{25}$ While ETs publish regular data regarding the claims that they receive and how those claims are resolved, there is limited information beyond these headline statistics. In particular, it is impossible to tell whether specific demographic groups are more or less likely to pursue their claims to an ET. As studies have found in other jurisdictions, there is an identifiable risk in age discrimination law that older women and younger workers, and those

\footnotetext{
${ }^{24}$ Ibid 10

${ }^{25}$ Ibid 3.
} 
who experience intersectional discrimination, will be unable or unwilling to pursue their rights to tribunal. ${ }^{26}$ Given the gaps in official data, a more creative empirical means of examining these issues is required.

It is here that making ET decisions available online could make a radical difference. Online publication potentially reduces the cost, time and jurisdictional limitations of seeking hardcopy files. It may assist advocates to frame and refine their arguments, at both first instance and on appeal. ${ }^{27}$ It may also help individuals - if they have the inclination and capacity to navigate the website - to see others who have pursued their rights, and how their claims have resolved. This could fulfil an important educative function. ${ }^{28}$ Online publication could also perform a deterrent function, as employers become more attuned to the reputational impacts of having a claim filed against them. ${ }^{29}$ This may help to create a culture of compliance, as employers realise there are consequences for discrimination. ${ }^{30}$ Thus, the House of Commons Women and Equalities Committee has argued that 'One simple change that can enable individual litigation to achieve wider change is enabling people to access and learn from previous judgments', such as through the online publication of ET decisions. ${ }^{31}$

\footnotetext{
${ }^{26}$ In Australia, see Alysia Blackham, 'Why Do Employment Age Discrimination Cases Fail? An Analysis of Australian Case Law' (2020) 42(1) Sydney Law Review 1; Alysia Blackham and Jeromey Temple, 'Intersectional Discrimination in Australia: An Empirical Critique of the Legal Framework' (2020) 43(3) UNSW Law Journal; in the USA, see Michael Schuster and Christopher S Miller, 'An Empirical Assessment of the Age Discrimination in Employment Act' (1984) 38(1) ILR Review 64.

27 Jamie Anderson, Employment Tribunal Judgments Online (10 February 2017) Jamie Anderson $<$ http://www.jamieandersonbarrister.co.uk/updates/uncategorised/employment-tribunal-judgments-online/>;

Jamie Anderson, Employment Tribunal Judgments Online (Revisited) (1 July 2020) Jamie Anderson $<$ http://www.jamieandersonbarrister.co.uk/updates/uncategorised/employment-tribunal-judgments-onlinerevisited/>.

${ }^{28}$ See similarly Dominique Allen and Alysia Blackham, 'Under Wraps: Secrecy, Confidentiality and the Enforcement of Equality Law in Australia and the UK' (2019) 43(2) Melbourne University Law Review 384.

29 See similarly ibid; Employment Tribunal Decisions Go Online Osborne Clarke $<$ https://www.osborneclarke.com/insights/employment-tribunal-decisions-go-online/>.

${ }^{30}$ Women and Equalities Committee, 'Enforcing the Equality Act: The Law and the Role of the Equality and Human Rights Commission' (Tenth Report of Session 2017-19 HC 1470, 30 July 2019) 86, 55 [192]

$<$ https://publications.parliament.uk/pa/cm201719/cmselect/cmwomeq/1470/1470.pdf $>$.

${ }^{31}$ Ibid 60 [217].
} 
More generally, then, making ET decisions relatively accessible is an important step in the broader project of increasing transparency in labour law and equality law. Equality law in particular is shrouded in secrecy, with most claims resolved via confidential conciliation with nondisclosure agreements attached. ${ }^{32}$ Limited information is released publicly about the claims that are brought and settled in equality law, partly due to the onerous secrecy obligations imposed on statutory equality agencies and Acas. ${ }^{33}$ A lack of transparency in this area can have damaging consequences for legal development, and inhibits our ability to address systemic discrimination and identify repeat offenders. Making claims confidential - and cases inaccessible - risks relegating discrimination law and labour law more generally to the private sphere. ${ }^{34}$ Publishing ET decisions online can therefore be seen as part of a broader, radical project in seeking transparency in discrimination and labour law.

That said, online publication poses a number of risks. There are already a number of barriers to individuals pursuing their legal rights; a permanent online record of an individual's litigation history might well operate as a further deterrent to claiming. ${ }^{35}$ Concerns have been raised that employers might search for prospective employees on the ET decision website; it is likely to be difficult to challenge any victimisation of this nature. ${ }^{36}$ There is therefore a need to balance the benefits of transparency and accessibility with protections for individuals and their privacy,

\footnotetext{
${ }^{32}$ Alysia Blackham and Dominique Allen, 'Resolving Discrimination Claims Outside the Courts: Alternative Dispute Resolution in Australia and the United Kingdom' (2019) 31 Australian Journal of Labour Law 253. See also Women and Equalities Committee, 'The Use of Non-Disclosure Agreements in Discrimination Cases' (Ninth Report of Session 2017-19 HC 1720, 11 June 2019) 70.

${ }^{33}$ Allen and Blackham, above $\mathrm{n} 28$.

${ }^{34}$ Margaret Thornton, 'The Public/Private Dichotomy: Gendered and Discriminatory' (1991) 18(4) Journal of Law and Society 448, 457; Margaret Thornton, 'Equivocations of Conciliation: The Resolution of Discrimination Complaints in Australia' (1989) 52(6) The Modern Law Review 733, 735.

35 'Online Tribunal Decision Database, and Anonymity Orders' on Stammeringlaw (19 November 2019) $<$ https://www.stammeringlaw.org.uk/employment/resolving-employment-disputes/online-tribunal-decisiondatabase-anonymity-orders/ $>$. See the claimant's unsuccessful argument to this effect in Kirkham v United Kingdom Research and Innovation [2019] UKET 2501482/2018. In that case an anonymity order was refused.

${ }^{36}$ Anderson, above n 27.
} 
including those under Article 8 of the European Convention on Human Rights and the Human Rights Act 1998, and the Data Protection Act 2018.

These issues are keenly illustrated in the EAT decision in $X v Y .{ }^{37}$ In that case, the ET judgment referred to the claimant's transgender status and mental health, in the context of explaining why a claim for unpaid wages and holiday pay was out of time. The claimant was not present at the hearing due to his health; he had not expected these matters to be raised in the hearing or judgment, and 'was aghast when he saw the contents of the Judgment.' 38 The EAT made an anonymity order to protect the claimant's Article 8 rights to privacy and family life, ${ }^{39}$ however, the relevant passages were not redacted from the judgment.

ET decisions have now been available online for over three years. The ET decision website remains difficult to navigate, with a fairly basic search function, and the vast majority of decisions are withdrawn (whether settled or not). ${ }^{40}$ There is no way to filter out withdrawn cases. ${ }^{41}$ This (perhaps inadvertent) opacity may help to protect individuals from future employment repercussions due to their history of litigation. ${ }^{42}$

That said, the comparative ease with which ET decisions may now be analysed is illustrated by Bengtsson's examination of age stereotyping in CJEU and ET decisions. ${ }^{43}$ Bengtsson's study draws on a sample of 100 full ET decisions relating to direct age discrimination, handed down from 1 October 2006 to 1 April 2018. While older decisions were sourced through a

\footnotetext{
37 [2019] UKEAT/0302/18/RN.

38 Ibid [11].

${ }^{39}$ See Employment Tribunals (Constitution and Rules of Procedure) Regulations 2013, SI 2013/1237, sch 1, reg 50 .

${ }^{40}$ Anderson, above n 27.

${ }^{41}$ Ibid.

${ }^{42}$ Anderson, above $\mathrm{n} 27$.

${ }^{43}$ Lyndsey Bengtsson, 'Addressing Age Stereotyping against Older Workers in Employment: The CJEU and UK Approach’ (2020) 62(1) International Journal of Law and Management 67.
} 
search of the internet, Michael Rubenstein Publishing and obtaining full judgments through written requests to Bury St Edmunds, more recent decisions were obtained through the ET website. ${ }^{44}$ Given the ease with which the author could access more recent decisions, it is unsurprising that the sample in this study significantly favours later decisions, with 17 of the 100 cases analysed filed in 2017, and another 19 filed in 2016 (36\% of the total sample). ${ }^{45}$ Thus, while making ET decisions available online will not just assist labour law researchers, the advantages of this shift for academic research cannot be understated.

\section{$3 \quad$ METHOD}

In this study, then, I use this emerging 'dataset' of online ET decisions to critique the individual enforcement of age discrimination law in the UK. While age discrimination law has a number of particularities, including the ability to justify direct age discrimination, focusing on one area of claiming offers a useful lens for directing our attention to how ETs and individual enforcement are operating. Further, age discrimination law is particularly interesting as it potentially covers individuals of all ages; anyone, of any age, could potentially file an age discrimination claim. A study of claimant demographics is therefore particularly revealing in this jurisdiction. This study of ET cases is part of a broader program of work, involving a multiyear mixed methods study of the enforcement of age discrimination law in the UK and Australia. ${ }^{46}$ Examination of the cases that progress to tribunal is but one part of this enforcement puzzle. ${ }^{47}$

\footnotetext{
${ }^{44}$ Ibid 69.

${ }^{45}$ Author's analysis of the case sample: see Ibid 89-91.

${ }^{46}$ For further details of this project, and other outputs, see ageworks.info

${ }^{47} \mathrm{On} \mathrm{ADR}$ as another part of this puzzle, see Blackham and Allen, above n 32.
} 
This study uses qualitative and quantitative content analysis and doctrinal analysis to analyse ET age discrimination cases. ${ }^{48}$ Unlike doctrinal analysis, which aims to harmonise or systematise texts, content analysis focuses on themes in texts. ${ }^{49}$ Content analysis is particularly useful for analysing cases where there are many decisions of a similar precedential weight (i.e. many first instance decisions) and where we are concerned with the pattern across cases, rather than a nuanced and deep understanding of one case. ${ }^{50}$ What matters for content analysis is the collective - not individual — insights from cases: '[c]ontent analysts ... assemble a chorus, listening to the sound the cases make together'. ${ }^{51}$ This approach is particularly apt for discrimination law, as most decisions are heard and decided at first instance, and few cases progress to the higher courts.

There is a long tradition of content analysis of case law: ${ }^{52}$ in the USA, Schuster and Miller, ${ }^{53}$ and Feild and Holley ${ }^{54}$ used quantitative analysis to retrospectively study judicial reasoning; Schuster and Miller in particular focused on the outcomes of age discrimination claims. ${ }^{55} \mathrm{In}$ the UK, Irving's study (discussed above) utilised qualitative and quantitative content analysis of ET decisions in age discrimination cases. ${ }^{56}$ In Australia, Blackham used qualitative and quantitative content analysis to examine 108 age discrimination cases handed down across Australian jurisdictions from the 1990 s to 31 December $2017 ;{ }^{57}$ that study found only 12

\footnotetext{
${ }^{48}$ Lisa Webley, 'Qualitative Approaches to Empirical Legal Research' in Peter Cane and Herbert M Kritzer (eds), The Oxford handbook of empirical legal research (Oxford University Press, 2010) 926, 941.

${ }^{49}$ See Mark van Hoecke, 'Legal Doctrine: Which Method(s) for What Kind of Discipline?' in Mark van Hoecke (ed), Methodologies of legal research: what kind of method for what kind of discipline? (Hart, 2011) 1, 11-17.

${ }^{50}$ Mark A Hall and Ronald F Wright, 'Systematic Content Analysis of Judicial Opinions' (2008) 96(1) California Law Review 63, 66.

${ }^{51}$ Ibid 76.

${ }^{52}$ See, eg, Fred Kort, 'Predicting Supreme Court Decisions Mathematically: A Quantitative Analysis of the "Right to Counsel" Cases' (1957) 51(1) The American Political Science Review 1. Kort used quantitative analysis to predict claim outcomes ('jurimetrics').

${ }^{53}$ Hall and Wright, above $\mathrm{n} 50$.

${ }^{54}$ Hubert S Feild and William H Holley, 'The Relationship of Performance Appraisal System Characteristics to Verdicts in Selected Employment Discrimination Cases' (1982) 25(2) Academy of Management Journal 392.

${ }^{55}$ Schuster and Miller, above n 26.

${ }^{56}$ Irving, above $\mathrm{n} 14$.

${ }^{57}$ Blackham, above $\mathrm{n} 26$.
} 
successful substantive age discrimination decisions in Australia. ${ }^{58}$ This study builds on and extends this existing scholarship.

Like doctrinal research, content analysis first involves identifying documents. The universe of documents for this study was all ET decisions relating to age discrimination published on the GOV.UK ET decisions website, from the first decisions being uploaded to the website (February 2017) until 17 April 2019, ${ }^{59}$ that is, a period of just over two years.

Second, the sample of texts for analysis was determined. The sample of texts was identified by searching the GOV.UK ET decisions website for age discrimination decisions, using the jurisdiction codes on the website itself. To expedite the collection of this sample, I used the Python programming language to pull data relating to age discrimination decisions from the ET website, and insert it into a spreadsheet. ${ }^{60}$ The ET decision website includes key information for each relevant decision, including the jurisdiction (here, focusing on age discrimination, but also other grounds of claim), the location of the Tribunal (Scotland, or England and Wales), the gender of the complainant (identified by their title - Mr, Ms or Mrs), the date of the decision, and the nature of the decision (preliminary, withdrawal, final, and so on). This information was added to the spreadsheet. I also converted PDF files of the decisions to text, to allow the identification and extraction of key words, including those relating to legal representation (and the name of the practitioner), and whether a claim was withdrawn.

\footnotetext{
58 Ibid.

${ }^{59}$ GOV.UK, above $\mathrm{n}$ 1. Some decisions handed down earlier than February 2017 had been uploaded to the website, dating back to 14 July 2016. While certainly not comprehensive for this period, these decisions were included for the purposes of this analysis, adding four decisions to the sample which were decided prior to February 2017.

${ }^{60}$ The code is available from the author upon request.
} 
My analysis of NI decisions was conducted separately, as NI has a separate website for uploading first instance decisions. While NI has 'been online' for a much longer period, I chose to match the sample to the available decisions in England and Wales and Scotland - that is, from February 2017 to 17 April 2019. This added 15 cases to my sample for analysis.

Recognising that cases may continue to progress over time, and that a number of claims in the sample had not been finally resolved as at 17 April 2019, the data collected was updated for the case numbers within the sample, to reflect each case's status and all case developments up to 11 January 2020. Cases with multiple decisions (for example, a preliminary hearing and/or reconsideration) were added only once to the sample, aggregating the issues for consideration. The sample was refined to exclude four cases: two had duplicate entries; ${ }^{61}$ one had the wrong decision attached, so could not be analysed; ${ }^{62}$ and one did not relate to any particular protected characteristic (age appeared to have been selected as a default to facilitate its entry into the database). ${ }^{63}$ I identified eight instances where case numbers had been duplicated, but the cases involved different claimants and respondents; these appeared to reflect errors in the manual inputting of case details. These cases were retained in the sample. With these refinements, the sample included 1208 age discrimination cases and 1563 published decisions, spanning 7829 pages.

Third, the texts were coded manually using themes derived from the literature and the documents themselves, ${ }^{64}$ and analysed using qualitative and quantitative methods. ${ }^{65}$

\footnotetext{
${ }^{61}$ Sharpe v Plympton Academy [2017] UKET 1400688/2017; Tarbuck v Peninsula Business Services Ltd [2019] UKET 2404056/2014.

${ }^{62}$ Dixon v NHS Digital [2017] UKET 1801127/2017.

${ }^{63}$ Colquhoun v Glasgow City Council [2017] UKET S/4104871/2017.

${ }^{64}$ Gery W Ryan and H Russell Bernard, 'Data Management and Analysis Methods' in Norman K Denzin and Yvonna S Lincoln (eds), Collecting and interpreting qualitative materials (Sage, 2nd ed, 2003) 259, $275-6$.

${ }^{65}$ Further details of these methods and results are on file with the author and available on request.
} 
Of the 1208 cases in the sample, $804(66.6 \%)$ had an age discrimination claim which was withdrawn or not pursued (including following settlement), whether or not the rest of the claim was withdrawn or not pursued. In an additional 34 cases, the age claim disappeared - most likely having been withdrawn or abandoned over the course of proceedings, though it was not possible to tell definitively.

These figures are lower than UK Tribunal statistics for age discrimination claims: in 2017-18, for example, $18 \%$ of claims resulted in Acas conciliated settlements, $27 \%$ were withdrawn, and $38 \%$ were dismissed upon withdrawal; in total, this represents $83 \%$ of claims (see Table 1 ). This disparity may be because the period I studied does not align neatly with the period reported in the ET statistics. That said, uploading decisions to the ET website appears to be a manual process, dependent on individual tribunal registries. There can be a delay in uploading decisions, and there is a risk that not all decisions are uploaded. ${ }^{66}$ This may limit the comprehensiveness and reliability of the ET decision website for analysing these sorts of statistics.

\section{Table 1: INSERT TABLE 1 ABOUT HERE}

Acknowledging the potential limits of these decisions as a source of data, there are still revealing insights that can be gathered from the decisions themselves. Across the sample, there

${ }^{66}$ Cf Judge Eady QC in Ameyaw v Pricewaterhousecoopers Services Ltd [2019] UKEAT 0244_18_0401 (4 January 2019) [49]. 
were 244 substantive decisions, and 162 interlocutory decisions. There were 43 cases where age discrimination claims were successful.

In relation to the demographics of claimants, a few clear trends emerged. First, where the age or age range of the claimant was specified (138 cases), claimants had a median age of $57 .{ }^{67}$ Where possible to discern, the majority of claims -136 - related to a claimant who alleged that they were seen as 'too old'; only 20 claims related to claimants who were 'too young'. Older workers were substantially more likely to bring a claim than younger workers. ${ }^{68}$

Second, in relation to gender, the sample included 664 male claimants, and 573 female claimants, as determined using claimants' titles (Mr, Miss, Ms, Mrs, or - in the case of $\mathrm{Dr}-$ pronouns used in the decision itself). ${ }^{69}$ Some cases involved multiple claimants - where possible, the gender of each individual claimant was added to this analysis, meaning the numbers exceed $1208 .{ }^{70}$ In some claims, the gender of the claimant was not specified - these cases were omitted from the gender analysis.

Men were therefore slightly more likely to bring a claim than women. This disparity increases once we filter out withdrawn or probably withdrawn claims. When considering only claims

\footnotetext{
${ }^{67}$ Where the claimant's age was expressed as an age range (e.g. 60+, under 35), this was analysed as the specified age (e.g. 60, 35 respectively). This is a blunt tool, which is why the median age is used for this analysis, not the mean. This analysis does not necessarily accurately capture the age of multiple claimants to a claim. Where multiple claimants were involved in a decision, the lead claimant's age was used for analysis. Typically, though, multiple claimants fell within a similar age range.

${ }^{68}$ This is consistent with Irving's findings: in her study, of 620 folio reports which specified whether claimants were too old, too young or belonged to a disadvantaged age group, 6.8\% (42) were too young, 91.1\% (565) were too old and 2.1\% (13) belonged to a disadvantaged age group: Irving, above n 14, 90.

${ }^{69}$ There was no explicit recognition in the titles of claimants who were gender diverse. This could therefore not be included in the analysis.

${ }^{70}$ Though, for some cases, the full gender breakdown was not possible to discern; this was analysed as one male claimant, and one female claimant, though the actual numbers will be higher: e.g. Jenkins v Tesco Stores Limited [2018] UKET 3401288/2016, which was coded as 1,1; McCloud $v$ The Lord Chancellor [2017] UKET $2201483 / 2015$, also coded as 1,1 .
} 
that are not withdrawn, there were 218 male claimants and 173 female claimants. Table 2 analyses withdrawal rates by gender across this sample; women represent a smaller proportion of claimants once withdrawn claims are removed, indicating that women are slightly more likely to withdraw their claim.

\section{Table 2: INSERT TABLE 2 ABOUT HERE}

Third, many claims involved multiple causes of action, the most common being unfair dismissal (764); breach of contract (337); disability discrimination (284); sex discrimination (267); race discrimination (245); and unlawful deduction from wages (282).

Fourth, where possible to discern, many cases related to dismissal (127), retirement (5) and redundancy (33); that is, the end of the working relationship. Other claims relating to matters during or at the commencement of the employment relationship were less common, including recruitment (23), training (3), promotion (8), demotion (3), working time (23), benefits (15) and performance processes (18). Harassment, however, or 'everyday' ageism, was fairly common (29).

Fifth, it is possible to examine representation at Tribunal, acknowledging that people may have more than one type of representation (for example, over two separate hearings, or two days of hearing, or appearing in person with assistance). For claimants, representation was specified in 538 cases. Nearly half (48.1\% or 259 claimants) appeared in person, though 187 (34.7\%) were legally represented. Eighty-four claimants had some other form of representation or assistance (e.g. by a friend, spouse, or parent, or - rarely - a union representative), and 28 did not appear. For respondents, where representation was specified (541 cases), only 28 appeared 'in person' 
(that is, without external representation); 446 were legally represented (82.4\%), and 48 had some other form of representation. Twenty-two did not appear, and one attended to observe only.

Thus, there was a substantial disparity in these cases between the levels of legal representation for claimants and respondents: claimants were far less likely to be legally represented, but often faced a respondent who was legally represented. This likely means that claimants were substantially disadvantaged in putting forward their case. It was particularly rare for a claimant to be legally represented, but for a respondent to not be represented. Angeli v The Orthopaedic Footwear Company $L_{t d}{ }^{71}$ was a rare case where the claimant was represented, but the respondent was not; that said, the claimant only briefed counsel one week prior to the hearing, likely limiting the benefit of that representation.

If we exclude withdrawn and probably withdrawn cases and preliminary cases from our analysis, there were 215 substantive cases that actually dealt with an age discrimination claim. Of these cases, only 43 (20\%) were successful for the age discrimination claim specifically; there were 7 cases where success in the age discrimination claim was unclear. 'Success' was defined as success for the claimant overall; this could be at the ET or later on appeal. Sargeant $v$ London Fire and Emergency Planning Authority, ${ }^{72}$ for example, was successful at the Court of Appeal, ${ }^{73}$ and leave to appeal to the Supreme Court was refused. This was counted as 'success'. That said, only three cases progressed to the EAT over this period - Heskett ${ }^{74}$ Sargeant and McCloud $;^{75}$ the latter two cases progressed to the Court of Appeal.

\footnotetext{
${ }^{71}$ [2019] UKET 2201663/2018.

72 [2017] UKET 2202235/2015.

${ }^{73}$ Lord Chancellor v McCloud [2018] EWCA Civ 2844 (20 December 2018), [2019] WLR(D) 1.

${ }^{74}$ Heskett $v$ The Secretary of State for Justice [2019] UKEAT/0149/18/DA.

${ }^{75}$ Lord Chancellor v McCloud [2018] EWCA Civ 2844 (20 December 2018), [2019] WLR(D) 1.
} 
The median age of claimants in successful claims where age was specified (22 cases) was 59.5, which was slightly higher than for the general claimant population (57). Twenty-four successful cases involved claimants who alleged they were seen as 'too old'; only six involved claimants who alleged they were 'too young'. ${ }^{76}$ The majority (31) of successful claimants were men; only 17 successful claimants were women. ${ }^{77}$ In 20 successful cases the claimant was legally represented (46.5\%), which is substantially higher than for the general sample of cases (34.7\%) and for substantive cases where the claimant was not successful (36.4\% represented) (see Table 3). Thus, legal representation appears to be associated with claimant success.

\section{Table 3: INSERT TABLE 3 ABOUT HERE}

Of the successful cases, $10(23.2 \%)$ were successful due to rule $21 .{ }^{78}$ Rule 21 says:

(1) Where on the expiry of the time limit ... no response has been presented, or any response received has been rejected and no application for a reconsideration is outstanding, or where the respondent has stated that no part of the claim is contested, paragraphs (2) and (3) shall apply. (2) An Employment Judge shall decide whether on the available material (which may include further information which the parties are required by a Judge to provide), a determination can properly be made of the claim, or part of it. To the extent that a determination can be made, the Judge shall issue a judgment accordingly. Otherwise, a hearing shall be fixed before a Judge alone.

\footnotetext{
${ }^{76}$ One of these cases involved a claimant who was classified as both too old and too young (where a young person also associated with an older colleague).

${ }^{77}$ These numbers do not add to 43 given the multiple claimants in Sargeant $v$ London Fire and Emergency Planning Authority [2017] UKET 2202235/2015 and McCloud v The Lord Chancellor [2017] UKET 2201483/2015.

${ }^{78}$ In one case a default judgment was later revoked.
} 
(3) The respondent shall be entitled to notice of any hearings and decisions of the Tribunal but, unless and until an extension of time is granted, shall only be entitled to participate in any hearing to the extent permitted by the Judge.

In all bar two of these decisions, there was no full written judgment uploaded onto the ET website (presumably because the claimant did not request written reasons). Indeed, 17 successful cases had no full record of the ET's reasons online. This demonstrates a significant gap in the ET 'dataset', as full written reasons are often not requested or uploaded.

Eleven cases in the sample involved respondent companies that were explicitly noted to be in liquidation, and a further two with respondent companies in administration. Five claims against respondents in liquidation were successful (though four were against the same company); one against a company in administration was successful. This was a much higher success rate than for the general case sample.

Overall, then, this 'dataset' of age discrimination decisions indicates that age discrimination law is more likely to be used, and more likely to be used successfully, by older men. Claims most often relate to dismissal, and are more likely to be successful if assisted by legal representation. The vast majority of complaints are withdrawn. This is consistent with Irving's earlier study, ${ }^{79}$ and with findings in other jurisdictions. ${ }^{80}$

\footnotetext{
${ }^{79}$ Irving, above n 14.

${ }^{80}$ Blackham, above n 26; Schuster and Miller, above n 26.
} 
To illustrate how these new forms of data might be used in practice, in this Part I consider the issue of time, which manifests across two interrelated issues: time limits for bringing an ET claim, and ET delays.

Complaints relating to work under the Equality Act 2010 are subject to time limits under s 123(1), which says:

proceedings ... may not be brought after the end of-

(a) the period of 3 months starting with the date of the act to which the complaint relates, or

(b) such other period as the employment tribunal thinks just and equitable

though this period is extended to facilitate Acas conciliation. ${ }^{81}$ Conduct which extends 'over a period is to be treated as done at the end of the period' ${ }^{82}$ This is a shorter time limit than that for claims in the civil courts (the latter is set at 6 months). ${ }^{83}$

Time limits of this nature are not precluded by EU law. For example, Article 9 of Council Directive 2000/78/EC of 27 November 2000 establishing a general framework for equal treatment in employment and occupation ${ }^{84}$ ('the Framework Directive') says:

1. Member States shall ensure that judicial and/or administrative procedures, including where they deem it appropriate conciliation procedures, for the enforcement of obligations under this Directive are available to all persons who consider themselves wronged by failure to apply the

\footnotetext{
${ }^{81}$ Equality Act 2010, s 140B. See similarly The Employment Equality (Age) Regulations (Northern Ireland) 2006, SI 2006/261, reg 48(1).

${ }^{82}$ Equality Act 2010, s 123(3).

${ }^{83}$ Ibid s 118.

${ }^{84}$ [2000] OJ L303/16.
} 
principle of equal treatment to them, even after the relationship in which the discrimination is alleged to have occurred has ended. ...

3. [Paragraph 1 is] without prejudice to national rules relating to time limits for bringing actions as regards the principle of equality of treatment.

In Bulicke ${ }^{85}$ the CJEU was clear that 'the question of time-limits for initiating a procedure for the enforcement of obligations under the Directive is not governed by European Union law.' 86 In that case, the CJEU held that the Framework Directive did not preclude a time limit requiring an age discrimination claim to be made within two months, so long as the time limit was not less favourable than that for similar domestic employment law actions, and the time limit (and point at which time started to run) did not render practically impossible or excessively difficult the exercise of those rights. ${ }^{87}$

Relatively short time limits for bringing claims to ETs are consistent with the original intention in establishing the ET system: that they should be a forum for resolving work-related disputes that 'is easily accessible, informal, speedy and inexpensive' ${ }^{88}$ Time limits are justified on a number of bases, including ensuring quality evidence (as witnesses may forget details over time, staff may leave, and documents may be destroyed ${ }^{89}$ ); not unduly burdening or prejudicing respondents with having to respond to antiquated claims; and allowing both parties to focus on their dispute, then move on. ${ }^{90}$ Hepple argues that the choice of a three-month time limit

85 Case C-246/09 Bulicke v Deutsche Büro Service GmbH, 2010.

${ }^{86}$ Ibid [24].

${ }^{87}$ Ibid [25].

${ }^{88}$ Lord Donovan (Chair), 'Royal Commission on Trade Unions and Employers' Associations' (Cmnd 3623, June 1968) 156 [572]. See also Law Commission, 'Employment Law Hearing Structures: Report' (HC308; Law Com No 390, 2020) 14; Susan Corby, 'British Employment Tribunals: From the Side-Lines to Centre Stage' (2015) 56(2) Labor History 161, 165.

${ }^{89}$ Law Commission, above n 88, 22.

${ }^{90}$ Ibid 15. 
specifically appears to be striving to make discrimination law consistent with time limits for unfair dismissal claims; there is no other discernible justification for distinguishing claims relating to work from those relating to non-work. ${ }^{91}$ Indeed, the Sex Discrimination Act 1975 the first statute that gave individuals the right to claim compensation for unlawful discrimination at work directly in a tribunal - set a time limit of three months, in similar terms to the Equality Act $2010 .{ }^{92}$

In relation to unfair dismissal claims, time limits have been in place since the introduction of individual unfair dismissal rights. ${ }^{93}$ The International Labour Recommendation Termination of Employment Recommendation, 1963 (No. 119) (which was influential in framing the recommendations of the Donovan report) merely recommended that individuals be required to bring claims of unfair dismissal 'within a reasonable time'. ${ }^{94}$ The Donovan report applied this strictly:

It is a necessary part of a satisfactory procedure that it should operate speedily. We think that an employee who wishes to lodge a complaint against his dismissal on the ground that it is unfair should be obliged to do so within five working days of dismissal, failing which he should be deemed to have forfeited his right of complaint. ${ }^{95}$

Ultimately, however, a more lenient limit of three months was imposed. ${ }^{96}$

${ }^{91}$ BA Hepple, Equality: The Legal Framework (Hart Publishing, 2nd ed, 2014) 206.

92 Sex Discrimination Act 1975, s 76.

${ }^{93}$ Industrial Relations Act 1971, re-enacted in the Trade Union and Labour Relations Act 1974, sch 1, s 21(4).

${ }^{94}$ International Labour Recommendation 119 Termination of Employment Recommendation, 1963 (No. 119) $\mathrm{cl}$

4, 11(4).

${ }^{95}$ Lord Donovan (Chair), above n 88, 147 [546].

${ }^{96}$ Industrial Relations Act 1971, re-enacted in the Trade Union and Labour Relations Act 1974, sch 1, s 21(4). 
While there are merits to the arguments in favour of time limits, they are undermined substantially by the extensive delays within the ET system. ETs are no longer (if they ever were) expeditious, accessible, or informal: as Corby argues, 'these yardsticks are essentially not applicable today'. ${ }^{97}$ Even writing in 2007, Dickens noted that:

It is commonplace that the ETs ... have not delivered the cheap, accessible, informal, expert, speedy route to justice in employment disputes they were intended to be, although they score above the ordinary courts on these measures. The gap between the original aspiration and reality is particularly marked in discrimination jurisdictions, notably equal pay cases where inordinate delays and complexity were described by the EAT as amounting to a denial of justice. ${ }^{98}$

Over time, ET cases have increased in complexity and value, and waiting times between filing and hearing have ballooned. ${ }^{99}$ As the Law Commission has noted, 'arguably the short, strict time limits ... [in ETs] are anomalous when claims may take as long as 10 or 12 months to proceed to a hearing.' 100 The Council of Employment Judges have noted that the current target for getting claims to hearing from the issue of proceedings is six months; a final remedy determination could take much longer. As the Council has recognised:

It is somewhat anomalous and anachronistic that the time limit in which an employee must identify, decide upon, formulate and decide to bring their claims is half as long as the time within which the tribunal thereafter aims to start the hearing of their claim. ${ }^{101}$

\footnotetext{
${ }^{97}$ Corby, above n 88,173 .

98 Dickens, above n 3, 478.

${ }^{99}$ Law Commission, above n 88, 14.

${ }^{100}$ Ibid.

${ }^{101}$ Council of Employment Judges submission, quoted in ibid 19.
} 
Delays in practice are even more substantial. In July 2019, it was reported that average waiting time between an ET receiving a claim and the claim being heard had increased to 237 days (nearly eight months), ${ }^{102}$ well in excess of the six-month target. Delays in the ET system have gotten worse over time, with the progressive defunding of the tribunal system. ${ }^{103}$ Rather than deal with the delays and structural limitations of the ET system, government policy has focused on limiting the number of claims that proceed to tribunal, including by introducing substantial fees for ET claims (subsequently ruled unlawful in the UNISON decision) ${ }^{104}$ and requiring claimants to notify Acas before submitting a tribunal claim, via the process of early conciliation. Since fees have been removed, the number of cases progressing to tribunal has again increased. ${ }^{105}$ Anecdotal evidence from practitioners indicates that delays in the ET system are substantial. ${ }^{106}$

Management information from Her Majesty's Court and Tribunal Service reveals just how chronic these delays are, and the extent to which they are compounding over time. Data from March 2019 to March 2020 for ETs (Table 4) shows the progressive increase in the average clearance time (that is, from receipt to disposal) for single ET claims; this has exceeded 30 weeks since August 2019. COVID-19 has further exacerbated these delays, with tribunals 'pausing' proceedings or being forced to work remotely. ${ }^{107}$

\footnotetext{
102 Delays at Employment Tribunal Reach 8 Months - up 14\% Last Year (29 July 2019) HR News $<\mathrm{http}$ //hrnews.co.uk/delays-at-employment-tribunal-reach-8-months-up-14-last-year/>.

${ }^{103}$ Kalyeena Makortoff, 'Employment Tribunal Claims Taking Eight Months to Be Heard' The Guardian, 29 July $2019<$ https://www.theguardian.com/money/2019/jul/29/employment-tribunal-claims-taking-eight-monthsto-be-heard>.

${ }^{104} R$ (on the application of UNISON) $v$ Lord Chancellor [2017] UKSC 51.

${ }^{105}$ Makortoff, above n 103.

${ }^{106}$ Melanie Newman, Labour Pains (27 July 2020) Law Gazette <https://www.lawgazette.co.uk/features/labourpains/5105139.article>.

${ }^{107}$ Employment Tribunals England \& Wales, '41st Meeting of National User Group: Minutes of the National User Group Meeting Held Via Zoom on 30 June 2020’ (2020) 6

$<$ https://assets.publishing.service.gov.uk/government/uploads/system/uploads/attachment_data/file/907738/ET_ NUG_June_2020_minutes.pdf>.
} 
Table 4: INSERT TABLE 4 ABOUT HERE

As Table 4 shows, the number of outstanding cases has also been progressively increasing. According to the minutes of the ET National User Group meeting held in June 2020, this is a chronic systemic issue, which has been further exacerbated by COVID-19. ${ }^{108}$ Outstanding cases have increased from approximately 10,000 single cases awaiting determination in March 2017, to 19,000 in March 2018, to 27,000 in March 2019. ${ }^{109}$ In the week ending 28 June 2020, there were 36,616 outstanding single cases in England, Wales and Scotland, up from the 'preCovid baseline' of 30,687 in March 2020. ${ }^{110}$ The number of outstanding cases is increasing by about $1 \%$ each week, and will likely exceed 40,000 by late summer or early autumn $2020 .{ }^{111}$

The cases in this sample provide an empirical illustration of the contradiction between strict time limits for bringing an action, and pervasive delays in the tribunal system. In this sample, delays in getting to hearing and a final remedy were significant. Where the date of the ET1 claim form was discernible in the ET decision ( 79 cases), the median time to decision was 278 days, though this ranged from 51 days to 1780 days. The time to a decision is represented in Table 5.

\section{Table 5: INSERT TABLE 5 ABOUT HERE}

These figures relate to the date of publication of the decision, rather than the date of hearing (which is what the relevant targets relate to), and could be the time to a preliminary decision,

\footnotetext{
108 Ibid.

${ }^{109}$ Ibid.

110 Ibid.

111 Ibid.
} 
or to a final remedy decision, or anything in between, which might account for the diversity in time taken.

That said, the longest time taken -1780 days - is nearly 5 years. This particular case - Fenton v Pennine Acute Hospitals Trust ${ }^{112}$ - had not even been resolved fully within that 1780 days; the remedy for the successful unfair dismissal claim was still to be determined. The delay was so extraordinarily long that the ET noted and apologised for the delay, ${ }^{113}$ which was variously attributable to postponements at the parties' request; the hospitalisation of the Employment Judge; illness of a panel member; the sheer scale of evidence presented by the parties; and 'pressure of judicial business'. ${ }^{114}$ Lengthy delays were also acknowledged (and apologised for) by the ET in Gibson v Newcastle upon Tyne Hospitals NHS Foundation Trust ${ }^{115}$ (653 days to final decision, remedy not yet determined); and in Kumar v Guy's and St Thomas' NHS Foundation Trust ${ }^{116}$ (673 days to final decision, where it was - somewhat ironically determined that the age discrimination claim was out of time by roughly 285 days; it took another 53 days for an application for reconsideration to be refused).

These lengthy proceedings and delays potentially make a mockery of strict time limits. Extensive delays undermine key arguments in favour of time limits: delays mean ETs are not a forum for the timely, efficient resolution of disputes; ${ }^{117}$ the quality of evidence is jeopardised; ${ }^{118}$ respondents have to respond to antiquated claims; and neither party can move on. ${ }^{119}$ Further, short time periods for filing a claim put an unreasonable burden on claimants,

\footnotetext{
112 [2017] UKET 2414119/2012.

${ }^{113}$ Ibid [2].

${ }^{114}$ Ibid [2].

115 [2018] UKET 2500035/2017.

116 [2017] UKET 2302841/2015.

117 Law Commission, above n 88, 14.

118 Ibid 22.

119 Ibid 15.
} 
who must undergo the process of "naming, blaming and claiming ${ }^{120}$ while under tight time pressure. As the National Association of Schoolmasters Union of Women Teachers submitted to the Law Commission,

Three months is not a lot of time in practice, especially when an employee has to absorb the situation, recognise they have been wronged, seek representation (if appropriate), go through early conciliation and begin the process of lodging a potential employment claim, including the associated paperwork. ${ }^{121}$

This time pressure compounds the mental burden of bringing a discrimination claim, particularly for members of impacted groups, who are likely to also be experiencing other forms of disadvantage and demands on their time (particularly for those with caring responsibilities). Indeed, for many claimants, managing a discrimination claim is on top of the already onerous process of finding a new job, or navigating a discriminatory or toxic workplace on a day-to-day basis. Managing a discrimination claim is already stressful and demanding, let alone under time pressure; short time limits are likely to affect claimants' mental wellbeing. ${ }^{122}$ Further, justifying why a claim is out of time - and why it would be just and equitable to extend time - forces claimants to disclose sensitive and personal information, which is now generally released into the public sphere with the online reporting of ET judgments. This is likely to have adverse effects on individual privacy and wellbeing. ${ }^{123}$ Unsurprisingly, then, the Law Commission has concluded that the current three-month time limit for bringing a claim to an

\footnotetext{
${ }^{120}$ William LF Felstiner, Richard L Abel and Austin Sarat, 'The Emergence and Transformation of Disputes: Naming, Blaming, Claiming ...' (1980) 15(3/4) Law \& Society Review 631.

${ }^{121}$ National Association of Schoolmasters Union of Women Teachers submission, quoted in Law Commission, above $\mathrm{n} 88,19$.

${ }^{122}$ LawWork submission, quoted in ibid.

${ }^{123}$ See, eg, $X v Y$ [2019] UKEAT/0302/18/RN, discussed above.
} 
ET is 'undesirably short', and has recommended that time limits be six months for all claims brought in an ET (including discrimination claims). ${ }^{124}$

The Law Commission's recommendations are given further weight by the results of this study. Among all decisions in this case sample, time limits were raised as an issue in 98 cases $(8.1 \%)$ : in 74 cases time limits proved fatal to a claim, and in 24 cases the claim (in all or part) was allowed to proceed. While ETs have discretion to extend time where it is 'just and equitable', this was rarely used in practice. In only 18 cases was time extended, ${ }^{125}$ noting that time could be extended for some complaints and not others. In other cases where time limits were not fatal, this was because it was determined that time had not expired; ${ }^{126}$ the issue had not yet been finally determined; ${ }^{127}$ or the conduct was a continuing act. ${ }^{128}$

${ }^{124}$ Law Commission, above n 88, 23.

${ }^{125}$ Harman v TMD Technologies Ltd [2017] UKET 3324348/2016; Kisitu v Inclusive Care Support Ltd [2019] UKET 3200241/2018 (claim successful); Kurianczyk v Integrated Cleaning Management Ltd [2019] UKET 2601254/2018 (later withdrawn); Morar v Thera Trust [2018] UKET 2600973/2018 (lawyer failed to submit claim properly; rectified within a few days); Craig $v$ The Commissioners for HMRC [2019] UKET 2501090/2017; Gibson v Newcastle upon Tyne Hospitals NHS Foundation Trust [2018] UKET 2500035/2017; Featherstone v Flair Flooring Supplies Ltd [2018] UKET 2424154/2017 (later withdrawn); Morgan v Yeovil District Hospital NHS Foundation Trust [2018] UKET 2423686/2017 (struck out due to failure to pay deposit); Nugent v Bucks Deli Ltd [2016] UKET 2400815/2016; Rose v Caterham School Ltd [2018] UKET 2304178/2017; Sandifer v HML Shaw Ltd [2017] UKET 2302143/2016; Balogun v Thorlands Housing Management Society [2017] UKET 2300909/2016; Cherian v Well Rose Ltd [2017] UKET 2300855/2017; Shirin v Wilson Barca LLP [2019] UKET 2208035/2016; Walsh v Government Legal Department [2019] UKET 2206970/2017; Stephenson v The Secretary of State for Justice [2017] UKET 1802719/2015; Winschief v SRS Realisations 2017 Ltd (in administration) [2019] UKET 1402539/2018; Ballentine v The Board of Governors, Lismore Comprehensive School [2019] NIIT 00051/18IT; 01014/17IT; 02819/16IT.

${ }^{126}$ See, for example, Waterloo v National Library of Scotland [2019] UKET S/4105348/17 (held to not to be out of time, but dismissed on merits); Wilson v Wilson Devonald Griffiths John Ltd [2017] UKET 1600416/2016 (held that actions placed claimant on gardening leave, and he was not dismissed; time therefore did not start to run, and claim was not out of time).

127 Brown v Kingspan Timber Solutions Ltd [2018] UKET 3325687/2017 (decline to decide; Tribunal to determine whether out of time); Basra v Flogas Britain Ltd [2018] UKET 2601057/2017 (to be determined whether time should be extended, later withdrawn).

128 Gibson v Newcastle upon Tyne Hospitals NHS Foundation Trust [2018] UKET 2500035/2017; Amu v Department for Work and Pensions [2018] UKET 1600465/2017; Roberts $v$ Voodoo Doll Ltd [2018] UKET 2403330/2017; Craig v The Commissioners for HMRC [2019] UKET 2501090/2017. 
The cases in this sample where time was at issue illustrate the strict, technical, and often problematic application of time limits to individual cases. ${ }^{129}$ The cases also show the many and compounding forms of disadvantage being experienced by individual claimants. For example, in O'Neill $v$ Jaeger Retail Ltd, ${ }^{130}$ the claimant had experienced a range of difficult circumstances, which could explain why her claim was out of time:

the claimant was struggling with her loss of confidence following two unsuccessful job applications, a period of illness due to flu, and most significantly three bereavements in her family in a short space of time. The letter from her GP in June 2018 confirmed that she was suffering from depression and not able to function properly or to deal with filling in forms, although the letter was silent as to when that began and how long it lasted. ${ }^{131}$

However, despite these complications, the ET held that the claimant had actually failed to submit her ET1 claim form as she was not aware that she had to file an ET claim herself:

She was under the misapprehension that she had done everything she needed to do by contacting ACAS to start early conciliation and by giving ACAS all the information about how she had been treated at work. Even though her friend Karen asked her what was happening, it was not until late February or early March that she contacted the conciliation officer at ACAS, Mr Murphy. That was about two months after the early conciliation certificate was issued. The misapprehension was corrected, and following escalation to his manager, David, the claim was presented in early April 2018. ${ }^{132}$

\footnotetext{
${ }^{129}$ This reflects the juridification of ETs and the rules they apply: Corby, above $\mathrm{n} 88$.

${ }^{130}$ [2019] UKET 4103815/2018.

${ }^{131}$ Ibid [31].

${ }^{132}$ Ibid [32].
} 
The claimant was able to act promptly once her misunderstanding was corrected, and she took no action to contact Acas or do research on their website for over six weeks after the early conciliation certificate was issued. ${ }^{133}$ The claimant had also received CAB advice prior to contacting Acas; the ET held that the $\mathrm{CAB}$ advisor must have informed her of the need to file an ET claim at the end of early conciliation. ${ }^{134}$ It was therefore not just and equitable to extend time. ${ }^{135}$ Thus, individual disadvantage is less significant than a mistake or misapprehension as to legal requirements (though these things must, to some extent, be interlinked); misunderstanding the law is no excuse.

As noted in the Law Commission's report on employment law hearing structures, one of the common challenges in adopting strict time limits relates to the delays likely occasioned by employees trying to resolve their disputes via internal grievance processes. ${ }^{136}$ Internal processes - either unwittingly or deliberately - can take longer than the three-month time period allowed for filing a claim. ${ }^{137}$ This was evident in the sample of ET cases studied for this paper: three cases in the sample were out of time due to the claimant waiting for employer appeal or grievance processes to run their course. It was held that this was not sufficient to extend time: ${ }^{138}$ time was not extended in any of these cases.

In Chatten $v$ Sky Subscribers Services Ltd,${ }^{139}$ for example, the ET noted that 'The claimant's case is simply that he genuinely believed that it was not necessary to present his claim form

\footnotetext{
${ }^{133}$ Ibid [36]-[37].

${ }^{134}$ Ibid [42].

${ }^{135}$ Ibid [44].

${ }^{136}$ Law Commission, above n 88, 18.

${ }^{137}$ Ibid.

${ }^{138}$ Sanderson v Boehringer Ingelheim UK [2018] UKET 2501398/2017; Chatten v Sky Subscribers Services Ltd [2018] UKET 2501396/2018 [28]; Gillespie v Santander UK PLC [2018] NIIT 05232/18IT (claimant was told by union had to wait for internal processes; did not confirm).

139 [2018] UKET 2501396/2018, [14].
} 
until such time as he received the outcome of his appeal. ${ }^{140}$ This was not the case, and nor was this sufficient to extend time, even if 'the respondent may be open to criticism for the length of time it took to undertake the claimant's appeal'. ${ }^{141}$

In the NI case of Gillespie v Santander $U K P L C^{142}$ the claimant alleged she was told by her union that she would need to wait for internal processes to conclude before she could lodge a claim. She also assumed that the union would file a claim on her behalf; this was not the case. ${ }^{143}$ The NIIT held that the claimant should have been far more proactive in managing her own claim:

When the claimant approached her union for assistance she was aware that she may have grounds for taking legal action against the respondent. It is simply not satisfactory that, on the claimant's case, she did not clarify such a fundamental issue as to whether or not it would be her responsibility or the union's responsibility to issue a claim if necessary. ... The tribunal is not satisfied that it was reasonable for the claimant to rely exclusively on advice given by [the union representative] in circumstances where the claimant had failed at an early stage to explore with [the union representative] the extent of the assistance which the union would give in respect of any potential tribunal claim. ${ }^{144}$

Ironically, the claimant was proactive: she wrote to her union representative and HR repeatedly in an attempt to expedite internal processes, ${ }^{145}$ but did not file her Tribunal claim 'because she

\footnotetext{
140 Ibid [14].

${ }^{141}$ Ibid [28].

142 [2018] NIIT 05232/18IT.

143 Ibid [52].

${ }^{144}$ Ibid [59], [65].

${ }^{145}$ Ibid [16]-[38].
} 
wanted to see if a solution to the problem could be found'. ${ }^{146}$ Unfortunately, this was not the form of 'responsibility' or action the NIIT required.

This approach to the enforcement of time limits - where waiting on employer processes does not mean it is 'just and equitable' to extend time - is likely to undermine the local resolution of discrimination allegations; to comply with time limits, claimants will need to escalate matters by filing their claim in the ET before local processes have run their course. This may undermine goodwill between the parties, and prevent the efficient resolution of disputes. Alternatively, it may leave claimants without recourse to an ET when the internal process is finally complete, as occurred in these three cases. Neither option is desirable.

Time limits are also legally complex, raising issues with their application in practice. For example, it can be practically difficult to tell when time starts running, making time limits a largely arbitrary limit for some claimants. In the NI case of Mawhinney $v$ Chief Constable of the Police Service of Northern Ireland ${ }^{147}$ time started to run when the claimants sat a test which was allegedly discriminatory, even if they had not yet been informed of the result:

We reject the submission that the cause of action did not complete until the claimants were advised of the outcome of the sift tool at which point they incurred injury to feeling, there being no loss incurred prior to then. We are not persuaded that completion of the cause was dependant on the state of knowledge of the claimants of the outcome of the sift test but find as a fact that the disadvantage to each claimant occurred on the date they were required to perform the computer based sift test, their performance in which meant they were unable thereafter to progress further in the promotions process. The claimants' anticipated and expressed concerns

\footnotetext{
${ }^{146}$ Ibid [38].

147 [2018] NIIT 04119/17IT; 04120/17IT.
} 
as to the disadvantage they were put by the sift test was confirmed to them on receipt of the respondent's confirmation on 20 March 2017 that they would not advance further. We agree this means that time began to run before the claimants knew for certain that they were unable to advance in the process as a result of their performance in the computer based assessment, but consider their lack of knowledge of this fact which goes to proof of discrimination is a factor relevant to whether it is just and equitable to extend time rather than delaying crystallisation of the cause of action and start of the primary time limit. ${ }^{148}$

Unfortunately the claimant did not present evidence to demonstrate it would be just and equitable to extend time, and the claim was held to be out of time.

While the claimants in Mawhinney were too late in bringing their claim, and assumed their claim would crystallise when they actually experienced loss, the claimant in the NI case of Barlow $v$ Gallagher $L t d^{149}$ faced the opposite problem, with the respondent arguing that the claim was premature, as the claimant's employment was ongoing, and he had not yet been made redundant; according to the respondent, the cause of action had not yet crystallised. ${ }^{150}$ The NIIT held, however, that the claim was not premature: the claimant had been informed that he would be excluded from an enhanced redundancy payment scheme, his grievance had been rejected, then appealed and rejected. For the NIIT,

There was an element of finality about this decision, and there was no suggestion that it could be further reviewed and changed. [The claimant] was treated differently from other workers, who got the pay rise and bonuses which were part of the enhanced redundancy scheme. We are satisfied that by the time he lodged his claims, he had been subjected to acts which potentially

\footnotetext{
${ }^{148}$ Ibid [72].

${ }^{149}$ [2017] NIIT 00924/15IT.

${ }^{150}$ Ibid [3].
} 
constituted unlawful discrimination by the respondent company and that he had suffered a detriment. $^{151}$

The question then becomes: if the claimant had waited until he was actually made redundant, would his exclusion from the enhanced redundancy payment scheme have been out of time? It is likely that this would depend on whether it was held to be conduct that extended over a period of time.

These examples demonstrate the potential complexity of navigating time limits, especially for litigants in person. For those who do not have legal training, these distinctions can appear absurd and arbitrary. Time limits are made even more complicated by the complex rules around how Acas conciliation extends time, which have generated confusion among claimants. ${ }^{152}$

Overall, then, the cases in this sample offer strong arguments against the application of strict time limits for discrimination complaints. The extension of time provisions are rarely exercised in a way that recognises the complex multiple burdens encountered by discrimination claimants. To resolve this, the Law Commission has recommended increasing time limits to six months for all ET claims. It is unclear whether this will be sufficient to address all these complexities; indeed, even a six-month time limit is likely to operate as a barrier for many claimants.

The online publication of ET decisions potentially heralds a new era of accessibility and openness in tribunal decision-making. However, this new system is only as good as the data

\footnotetext{
151 Ibid [3].

${ }^{152}$ Law Commission, above n 88, 21.
} 
that is inputted into it. Many cases in this particular sample did not have full written reasons attached to the online record; ETs often deliver their decisions verbally, and written reasons are not always requested by the parties. At best, then, this form of online publication will only represent a select sample of cases, and any research based on this 'data' must be similarly circumspect in its findings.

With these caveats, this paper has demonstrated the ways in which online ET decisions can be used to scrutinise and interrogate the individual enforcement of employment rights. Focusing on age discrimination decisions, this study has shown that claimant demographics are skewed towards those who are older, particularly men, and tend to focus on dismissal. This reveals, then, that there are substantial gaps in the enforcement of age discrimination law, particularly for young workers and older women, who experience substantial age discrimination at work. ${ }^{153}$ As we turn our attention to improving individual enforcement, and adopting mechanisms beyond the individual enforcement model, these gaps are highly illuminating in terms of where we should focus our attention and effort.

This paper has illustrated that the scope for using online ET decisions to enhance existing labour law research is wide. Readily accessible ET decisions could inform a vast range of research projects, on a myriad of issues. That said, while online databases can be analysed more expeditiously using programming tools, there is still a substantial amount of work involved in reading and sorting through this number of cases. Even once these cases had been inputted into a spreadsheet, it still took over a year to read and code these cases in full. A comprehensive

\footnotetext{
${ }^{153}$ See, eg, Diane Grant, 'Older Women, Work and the Impact of Discrimination' in Age Discrimination and Diversity: Multiple Discrimination from an Age Perspective (Cambridge University Press, 2011) 41; J Handy and D Davy, 'Gendered Ageism: Older Women's Experiences of Employment Agency Practices' (2007) 45(1) Asia Pacific Journal of Human Resources 85; Sian Moore, "No Matter What I Did I Would Still End up in the Same Position” Age as a Factor Defining Older Women's Experience of Labour Market Participation' (2009) 23(4) Work, Employment \& Society 655.
} 
project of this nature still requires considerable time and persistence to see to fruition. As academic workloads are further intensified following COVID-19 budget cuts, this work is even less likely to occur, unless pursued as part of $\mathrm{PhD}$ or postdoctoral studies or large funded projects.

A better way, then, to monitor the individual enforcement of labour and discrimination law rights would be through effective data collection by ETs and statutory agencies themselves. For example, annual ET statistics could examine claims lodged and outcomes by gender, ethnicity and migration status. This would be an important development for ensuring that judicial processes are accessible to all, including impacted groups.

Using time as a case study of how we might apply these methods to particular issues, this paper has empirically shown both the excessive delays that pervade the ET system, and the difficulties that arise with applying strict time limits to individual cases. ET decisions themselves are factually specific and complex; drawing on these decisions therefore represents an important means of giving context to and individual perspectives on systemic issues. ${ }^{154}$

As this study shows, taken together, ET delays and strict time limits risk substantially inhibiting access to justice. As the Supreme Court held in UNISON, access to the courts is fundamental to the rule of law:

Courts exist in order to ensure that the laws made by Parliament, and the common law created by the courts themselves, are applied and enforced. ... In order for the courts to perform that role, people must in principle have unimpeded access to them. Without such access, laws are

\footnotetext{
${ }^{154}$ See also Barnard and Ludlow, above n 7.
} 
liable to become a dead letter, the work done by Parliament may be rendered nugatory, and the democratic election of Members of Parliament may become a meaningless charade. ... ${ }^{155}$

People and businesses need to know, on the one hand, that they will be able to enforce their rights if they have to do so, and, on the other hand, that if they fail to meet their obligations, there is likely to be a remedy against them. It is that knowledge which underpins everyday economic and social relations. ${ }^{156}$

Practical limits on claiming risk substantially inhibiting legal enforcement in the UK. This may undermine the rule of law, even if claiming is not impossible. ${ }^{157}$ As the Supreme Court opined: 'even an interference with access to the courts which is not insurmountable will be unlawful unless it can be justified as reasonably necessary to meet a legitimate objective. ${ }^{\text {'158 }}$ There is a strong argument that, given the extensive delays in the ET system, strict time limits for bringing a tribunal claim can no longer be justified as reasonably necessary.

Overall, then, this study empirically illustrates the very substantial barriers that stand in the way of individual claiming to enforce discrimination rights. Relying on individuals to enforce their rights in labour and discrimination law is unlikely to lead to meaningful structural change. ${ }^{159}$ There is a need for renewed emphasis on other, non-individualised methods of enforcement, including collective action, positive duties, and proactive enforcement by equality agencies. ${ }^{160}$

\footnotetext{
${ }^{155} R$ (on the application of UNISON) $v$ Lord Chancellor [2017] UKSC 51, [68].

${ }^{156}$ Ibid [71].

${ }^{157}$ Ibid [78].

${ }^{158}$ Ibid [89].

${ }^{159}$ Susan Sturm, 'Second Generation Employment Discrimination: A Structural Approach' (2001) 101(3)

Columbia Law Review 458.

${ }^{160}$ See generally the contributions to Linda Dickens (ed), Making Employment Rights Effective: Issues of Enforcement and Compliance (Hart, 2012).
} 


\begin{tabular}{|c|c|c|c|c|c|c|c|c|c|c|c|c|c|}
\hline & $\begin{array}{l}2007 / 0 \\
8\end{array}$ & $\begin{array}{l}2008 / 0 \\
9\end{array}$ & $\begin{array}{c}2009 / 1 \\
0\end{array}$ & $\begin{array}{c}2010 / 1 \\
1\end{array}$ & $\begin{array}{c}2011 / 1 \\
2\end{array}$ & $\begin{array}{c}2012 / 1 \\
3\end{array}$ & $\begin{array}{c}2013 / 1 \\
4\end{array}$ & $\begin{array}{c}2014 / 1 \\
5\end{array}$ & $\begin{array}{c}2015 / 1 \\
6\end{array}$ & $\begin{array}{c}2016 / 1 \\
7\end{array}$ & $\begin{array}{l}2017 / 1 \\
8\end{array}$ & $\begin{array}{l}2018 / 1 \\
9\end{array}$ & $\begin{array}{l}\text { Average 2007- } \\
19\end{array}$ \\
\hline Annual Total & 1,778 & 2,472 & 3,873 & 3,651 & 3,820 & 2,674 & 4,259 & 1,528 & 865 & 806 & 1,732 & 1,917 & 2,448 \\
\hline Acas Conciliated Settlements & $45 \%$ & $40 \%$ & $39 \%$ & $35 \%$ & $33 \%$ & $43 \%$ & $19 \%$ & $28 \%$ & $35 \%$ & $35 \%$ & $18 \%$ & $21 \%$ & $32.6 \%$ \\
\hline Withdrawn & $35 \%$ & $32 \%$ & $39 \%$ & $40 \%$ & $42 \%$ & $32 \%$ & $63 \%$ & $42 \%$ & $23 \%$ & $24 \%$ & $27 \%$ & $49 \%$ & $37.3 \%$ \\
\hline Successful at hearing & $3 \%$ & $2 \%$ & $2 \%$ & $2 \%$ & $1 \%$ & $4 \%$ & $2 \%$ & $2 \%$ & $2 \%$ & $2 \%$ & $1 \%$ & $1 \%$ & $2.0 \%$ \\
\hline Unsuccessful at hearing & $8 \%$ & $10 \%$ & $9 \%$ & $9 \%$ & $8 \%$ & $11 \%$ & $7 \%$ & $12 \%$ & $13 \%$ & $13 \%$ & $6 \%$ & $5 \%$ & $9.3 \%$ \\
\hline Struck Out (not at a hearing) & $4 \%$ & $10 \%$ & $7 \%$ & $10 \%$ & $13 \%$ & $6 \%$ & $4 \%$ & $6 \%$ & $12 \%$ & $4 \%$ & $7 \%$ & $9 \%$ & $7.7 \%$ \\
\hline Default judgment & $1 \%$ & $1 \%$ & $1 \%$ & $1 \%$ & $1 \%$ & $1 \%$ & $0 \%$ & $0 \%$ & $0 \%$ & $0 \%$ & $0 \%$ & $0 \%$ & $0.5 \%$ \\
\hline $\begin{array}{l}\text { Dismissed at a preliminary } \\
\text { hearing }\end{array}$ & $5 \%$ & $5 \%$ & $3 \%$ & $3 \%$ & $3 \%$ & $4 \%$ & $2 \%$ & $2 \%$ & $1 \%$ & $2 \%$ & $1 \%$ & $1 \%$ & $2.7 \%$ \\
\hline \multicolumn{2}{|l|}{ Dismissed Rule 27} & & & & & & $0 \%$ & $0 \%$ & $0 \%$ & $0 \%$ & $0 \%$ & $0 \%$ & $0.0 \%$ \\
\hline \multicolumn{3}{|l|}{ Dismissed Upon Withdrawal } & & & & & $4 \%$ & $8 \%$ & $12 \%$ & $19 \%$ & $38 \%$ & $12 \%$ & $15.5 \%$ \\
\hline Case Discontinued & & & & & & & $0 \%$ & $0 \%$ & $0 \%$ & $0 \%$ & $1 \%$ & $1 \%$ & $0.3 \%$ \\
\hline
\end{tabular}

Table 1: UK Employment Tribunal Disposals for age discrimination claims, by year, 2007-08 to 2018-19 (Source: UK Tribunal Statistics) 


\begin{tabular}{l|l|l|l|l|l|}
\hline \multicolumn{2}{|c|}{ Men } & \% of total & Women & $\%$ of total & \multicolumn{1}{l}{ Total } \\
\hline All cases & 664 & $53.7 \%$ & 573 & $46.3 \%$ & 1,237 \\
\hline Not withdrawn & 218 & $55.7 \%$ & 173 & $44.2 \%$ & 391 \\
\hline $\begin{array}{l}\% \quad \text { of claimants } \\
\text { remaining }\end{array}$ & $32.8 \%$ & & $30.2 \%$ & & $31.6 \%$ \\
\hline
\end{tabular}

Table 2: Withdrawal rate by gender, ET age discrimination decisions, February 2017 to April 2019

\begin{tabular}{|l|l|l|}
\hline \multicolumn{2}{|c|}{$\begin{array}{l}\text { Claimants } \\
\text { represented }\end{array}$} \\
\hline All cases (538) & 187 & $34.7 \%$ \\
\hline Successful & 20 & $46.5 \%$ \\
\hline substantive claims & & \\
\hline (43) & & \\
\hline Unsuccessful & 60 & $36.4 \%$ \\
substantive claims & & \\
\hline (165) & & \\
\hline
\end{tabular}

Table 3: Success and legal representation, ET age discrimination decisions, February 2017 to April 2019 


\begin{tabular}{|r|r|r|r|r|} 
Month & Receipts & Disposals & Outstanding \\
& & & Clearance Time \\
for Single Claims
\end{tabular}

Table 4: Management information, ETs, March 2019 to March 2020 (Source: HMCTS) 


\begin{tabular}{|l|r|}
\hline Number of days & \multicolumn{1}{|c|}{ Number } \\
to decision & of \\
\hline$<=100$ & 6 \\
\hline $101-200$ & 17 \\
\hline $201-300$ & 20 \\
\hline $301-400$ & 9 \\
\hline $401-500$ & 14 \\
\hline $501+$ & 13 \\
\hline Total & 79 \\
\hline
\end{tabular}

Table 5: Number of days to decision by number of cases, ET decision sample 


\section{University Library}

\section{- M M N E R VA A gateway to Melbourne's research publications}

Minerva Access is the Institutional Repository of The University of Melbourne

Author/s:

Blackham, A

Title:

Enforcing Rights in Employment Tribunals: Insights from Age Discrimination Claims in a New 'Dataset'

Date:

2021

Citation:

Blackham, A. (2021). Enforcing Rights in Employment Tribunals: Insights from Age Discrimination Claims in a New 'Dataset'. Legal Studies, 41 (3), pp.390-409. https:// doi.org/10.1017/lst.2021.11.

Persistent Link:

http://hdl.handle.net/11343/258897 